\title{
CHAPTER TWENTY
}

\section{GENDER STUDIES - EMOTIONS IN JEPTHA (1659)}

\author{
Kristine Steenbergh
}

Vondel's play Jeptha of Offerbelofte (Jephthah or Promise of Sacrifice, first published in 1659) has invited critical attention to the issues of its literary poetics as well as its representation of women. Vondel's introduction to his biblical tragedy calls explicit attention to the role of emotions in the play's Aristotelian poetics. Also, in adapting the story of the general who unwittingly promises to sacrifice his daughter, Vondel's play gives the anonymous biblical daughter the name Ifis ('strength'), and adds a mother named Filopaie. ${ }^{1}$ A central question in recent criticism that takes these two issues in its stride is concerned with the role of female emotions in Jeptha. Critics often view daughter Ifis as unemotional, whereas Filopaie's display of emotions is seen as excessive or even hysterical, and contrasted with Jeptha's role as the focus of the audience's emotions. ${ }^{2}$ This chapter will analyse the representation of the emotions in the context of the play's poetics from a gender perspective. I will argue that the play as a whole does not disapprove of Ifis's or Filopaie's emotions. Rather, an analysis of the play's gendered representation of the emotions shows how Jeptha's management of his emotions is explicitly contrasted with that of his daughter and wife to suggest that the rehearsal of strong passions in a theatrical context has a therapeutic effect. Vondel intuits that Aristotelian poetics can be harnessed as a means to achieve Catholic purification and salvation.

${ }^{1}$ John Christopherson of Cambridge University was the first to introduce the figure of the mother to his unpublished Greek play I $\varepsilon \varphi \theta \alpha \varepsilon$. The humanist dramatist George Buchanan wrote the neo-Latin Jephthes sive votum in 1544 . He also included a mother, named Storgê (parental love) and calls the daughter Ifis. In the Netherlands, the first dramatisation of the biblical tale was by a Capuchin monk in Ghent, J. C. van Lummene van Marke (1607). Abraham de Koning was the first to write a tragedy on Jeptha in Dutch: Jephthahs ende zijn Eenighe Dochters treur-spel (1615). Vondel was familiar with his play, which does not contain a mother figure and names the daughter Mirja. For a comparison of these plays, see Wijngaards' introduction to his edition of Jeptha, pp. 9-27.

${ }_{2}$ English would be Jephthah, but I choose Jeptha, since this is how the character is called in the play. 


\section{Poetics and Gender}

Whereas earlier Dutch playwrights were indebted to Seneca for their perception of emotions as disruptions that need to be eradicated, Vondel's drama stands out because of his exceptionally close adherence to Aristotelian poetics. In brief, this view of theatre aims to enable the audience of a tragedy to moderate their emotions precisely by letting them experience strong emotions in the theatre. In his analysis of the operations of Aristotelian poetics in Vondel's Jeptha, Jan Konst stresses that the 'coherent unity of the plot' is of crucial importance in achieving this effect of catharsis on the audience. This unity, in his view, is achieved by a focus on the character of Jeptha, who demonstrates the didactic intent of the play. Jeptha's intense doubts about his chosen course of action in the central acts of the play invite the audience to identify with him, so that their emotions 'develop parallel to Jeptha's psychological development' and climax at the beginning of the fifth act, when the protagonist realises that he was wrong to sacrifice his daughter. Because the spectators, together with Jeptha, experience strong feelings of pity and fear at that point, they achieve catharsis: they are purged of their emotions. ${ }^{3}$

Although Vondel gave Jeptha's daughter a name and introduced the character of Filopaie, who is absent in the Bible, Konst does not think the female characters fundamental to the tragedy's poetics. ${ }^{4}$ Filopaie is irrelevant to the emotional effect of the play; she is merely a 'secondary character. ${ }^{5}$ Indeed, in his view the mother's purpose in the play runs counter to the Aristotelian poetics of the play as a whole. Konst writes that Filopaie is portrayed more in accordance with Senecan-Scaligerean poetics, as a warning against the dangers of excessive emotion. Therefore, he writes, it is only when we look at the central character of Jeptha that we realise that Vondel's didactic purpose points in a different direction, that of Aristotelian poetics. ${ }^{6}$

From a feminist perspective, Agnes Sneller has commented on this exclusive focus on the character of Jeptha in the play's critical reception. She points out that when critics argue that the audience is able to identify with Jeptha and to share in his emotional development, the

\footnotetext{
${ }^{3}$ Konst, Woedende wraakghierigheidt, pp. 193, 51, 199 respectively.

${ }^{4}$ Konst, Fortuna, Fatum en Providentia Dei, p. 280.

Ibid., p. 50.

${ }^{6}$ Konst, Woedende wraakghierigheidt, p. 51.
} 
catharsis they experience is dependent on the sex of the individual audience member. If Jeptha is represented as a Renaissance man, the ideal woman in the play is a creature who does not develop at all and who acts in obedience, preferably without any resistance, like Ifis, or perhaps after extreme emotions, like Filopaie. The latter is portrayed in the initial scenes of the play as a woman who cannot control her emotions, Sneller argues, and even if she later proves to have been misled by her husband, the image that the audience retains of her is that of a vulnerable, emotional woman. Indeed, critics have accordingly seen her as a woman who cannot govern herself.' Riet Schenkeveld, too, has argued that Vondel's plays do not accord female characters much agency. She writes that in the rare cases in which women are portrayed positively, this often occurs in a context of atonement: 'The virgin martyrs bring the sacrifice of their sexuality in the most humiliating circumstances one can imagine, subjected to their male attackers with no will of their own.' ${ }^{8}$ Both Sneller and Schenkeveld read Vondel against the grain, and argue that the emotional purgation of the audience is only achieved at the cost of female characters, who are not allowed such development in their own right.

In his recent analysis of the tragedy in Vondel belicht (translated as Sovereignty as Inviolability: Vondel's Theatrical Explorations in the Dutch Republic), Frans-Willem Korsten counters the traditional emphasis on the character of Jeptha, and argues for the importance of Ifis and Filopaie to the plot. Korsten moves away from a strict focus on Aristotelian poetics to trace a gendered pattern of masculine sword and feminine distaff in the play. He concludes that Ifis's sacrifice establishes the sovereignty of the nation of Israel. ${ }^{9}$

In what follows, I will similarly analyse the play from a gender perspective rather than from the perspective of feminist criticism. Following Joan Scott, I am interested in the ways gender representations shape relations of power. In her seminal article 'Gender: A Useful Category of Historical Analysis', Scott defines gender not only as 'a constitutive element of social relationships based on perceived differences between the sexes', but also as a primary means by which power is articulated. It can be used this way to shape relations between the sexes, but, as Scott writes, 'concepts of power, though they may build on

\footnotetext{
7 Sneller, 'De marges centraal', p. 11 and passim.

8 Schenkeveld-van der Dussen, Vondel en 't vrouwelijke dier, p. 23.

9 Korsten, Vondel belicht, pp. 71-88; Sovereignty as Inviolability, pp. 69-89.
} 
gender, are not always literally about gender itself.' ${ }^{10}$ The binary opposition of gender is often used to enforce other oppositions in relations of power. Literary historians can therefore use gendered oppositions as an entrance into the power structures that take shape in a text. Scott writes: 'we must constantly ask not only what is at stake in proclamations or debates that invoke gender to explain or justify their positions, but also how implicit understandings of gender are being invoked and reinscribed." ${ }^{11}$ It is the task of the historian, she argues, to disrupt the seeming objectivity of gender structures, and to examine the nature of the debate that led to the appearance of a gendered concept. The relations of power to which Scott refers are often political, but her model can also be applied to other levels of power, such as early modern theatre's power to condition affective experience. Stage performances shaped the ways in which audience members came to name and interpret their emotions, as well as how they understood them as 'social and political currency.1. ${ }^{12}$ In this chapter, I will look at the gendered representation of emotions in the context of the play's religious subject matter as well as conflicting early modern views on the operations of emotions. If we do not accept the early modern stereotype of the woman's inability to control her emotions at face value, but read the gendered representation of emotions in Vondel's Jeptha as signifying relations of power, we see how Vondel's play uses gendered images to advocate the purging of the emotions through their expression in an isolated theatrical environment, and associates this process of purgation with the Catholic notions of purification and salvation.

\section{Moving Stones: Ifis and the Purgation of Grief}

Ifis is often described as an unimportant character. Konst, for example, remarks that her acceptance of a speedy death functions mainly to enable the portrayal of her father's inner turmoil, and that 'Ifis, because of her constant acquiescence, remains a flat character. ${ }^{13}$ Similarly, Sneller comments: 'And Ifis? She hardly participates. [...] Her obedience to her father is there in the beginning, and will last to the end. ${ }^{14}$ Piet Gerbrandy

10 Scott, 'Gender', p. 1069.

11 Ibid., 1074.

12 Rowe, 'Humoral Knowledge', p. 176.

13 Konst, Woedende wraakghierigheidt, pp. 147-48.

14 Sneller, 'De marges centraal', p. 8. 
dismisses her as a 'sanctimonious bore. ${ }^{15}$ I will argue here that if we read the play not for the plot but for its representation of emotions, it becomes clear that Ifis does not suffer from a lack of feeling or inner turmoil.

Indeed, Ifis is introduced as a woman with strong emotions. We are told that when Filopaie fainted at Jeptha's return from the battle against the Ammonites (thus missing the encounter between Ifis and her father), Ifis feared for her mother's life. She was in tears at her bedside, moaning, crying and sighing in distress. ${ }^{16}$ Moreover, the play repeatedly draws attention to Ifis's two months of intense grief in the mountains of Galaäd, where she went after learning of her father's vow. Ifis's stay in the mountains is not part of the action of the play - Vondel states that in order to fit the drama into Aristotle's unity of time, the play begins when Jeptha returns victorious from his battle against the Ephraimites, two months after his defeat of the Ammonites and his rash vow to God. Nevertheless, Ifis's period of mourning in the mountains is referred to time and again, as if to remind the audience of what happened there. ${ }^{17}$ Indeed, in his address to friends of the theatre ('Berecht'), Vondel chides George Buchanan for leaving Ifis's stay in the mountains out of his play to adhere to the Aristotelian unity of time.

Why is this stay in the mountains so crucial to Vondel's play? The expression of emotion that occurs in the isolated environment of the mountains is central to the play's representation of the operations of affect. When she returns to the palace, Ifis tells the Steward ('Hofmeester') that she bewailed her fate together with the virgins who accompanied her. She describes how they noisily tore off their garments, let down their hair, groaned, sighed and moaned. Echoes repeated their sound, which they in turn imitated, ${ }^{18}$ so that cries

15 '[...] vervelende kwezel', Gerbrandy, 'Tussen Seneca en Aristoteles,' p. 26. Dietz has characterized Ifis as a Stoic in 'Een mens gelijk', pp. 36-37.

16 '[...] en steende, en kermde, en zuchte in zulck een noot' (1.35).

17 See the dedicatory poem 11. 26-29; 'Berecht' ll. 4-6, 17; 'Inhoudt' 11. 13-15; in the play ll. 11-12, 93-98, 295, 419-30, 582-85, 828-31, 1597, 1930. It is strange, in this context, that Korsten states: 'How Iphis has talked in her period of absence is not known, but it certainly will not have been mere merry acceptance' (Korsten, Vondel belicht, p. 84; Sovereignty as Inviolability, p. 86). In a recent article, Van Gemert does acknowledge that Ifis mourned in the mountains: 'there has been ample lamentation (e.g. in vss. 419-38, 468-73 and 1595)'. She argues that, in his representation of Ifis as a powerful character, Vondel was inspired by De Koning's Jepthah (Van Gemert, 'Schuld en boete,' p. 134).

18 'Den galm geweckt, die lust schept na te baeuwen' (1. 471). 
resounded from rock to rock (1l. 468-82). In this description the virgins' retreat to the mountains is characterized as a time of strong emotions. The echoing rocks play an important role as the audience of the virgins' performance of grief. This is also evident from an earlier passage in which the effect of the echo figures prominently:

With my attendants I so long did go

And wander in these mountains to and fro,

And long enough for maidenhood have cried

And to our mourning echoing hills replied.

Both sun and moon in turns across the sky

Witness to how our all-pervading cry

Has moved the very rocks lying here and there. ${ }^{19}$

Here, the isolated mountainous environment is represented in terms reminiscent of a theatre, where the rocks take on the role of audience. The passage stresses the interaction between the women and the rocks by means of a pun: the word 'nagesteent' (to echo lamentingly) itself echoes the mountains, since 'steen' means stone. The women and their petrified audience enforce each other's emotions. The rocks are not mere sounding boards, as the final line of the passage stresses: they are moved by what they hear. This parallel between the interaction of Ifis and the rocks on the one hand, and that of actors and an audience is strengthened by Vondel's use of a similar image of impassioned rocks in his prefatory sonnet to Abraham de Koning's earlier dramatic version of the biblical tale. In that poem, Vondel stresses how the theatre has the power to make the audience experience events as if they truly happened. The poem states that when the maiden blood of Jeptha's daughter floods the stage 'everyone dies with her, and the stones wellnigh burst. ${ }^{20}$ In Vondel's Jeptha, the emotional interaction between Ifis and her audience of mountains purges her grief and enables her to master her emotions. She states that 'now there is nothing that will make me afraid' and 'I am ready now. The time for grief is past.'.

19 'Ick heb dus lang de heuvels op en neder / Met dezen rey bewandelt heene en weder, / Mijn' maeghdestaet, en jeught genoegh beweent. / De berghgalm heeft ons lijckklaght nagesteent. / De zon en maen, by beurte op haeren wagen, / Getuigen hoe ons al te druckigh klaegen / De rotsen zelf beweeghde, west en oost' (1l. 419-25). All translated quotations from Jeptha are taken from Peter King's translation, unless otherwise indicated.

${ }_{20}$ 'Dan stervet al met haer, dan bersten schier de steenen', De Koning, Jephthahs ende zijn eenighe dochters treurspel, Sig ${ }^{\star} 3 \mathrm{r}$.

21 ' $[\mathrm{N}] \mathrm{u}$ is' er niets dat my vervaeren kan' (1.585) and 'Ick sta bereit. de tijt is uit van treuren' (1. 704). 
This ability to purge one's passions in order to achieve mastery over them is described in gendered terms in the play. The chorus of virgins who accompanied Ifis to the mountains later sings the praise of her equanimity ('gelaetenheit', 1. 1639) and describes it as a stronger power than that which defeats armies, giants or lions. ${ }^{22}$ Ifis's patience is thus implicitly contrasted with the military heroism of Jeptha, which he secured with his rash vow to sacrifice her. In the same chorus, the virgins approve of those who are able to defeat their own will and desires, and value them higher than those famous for their use of reason or wisdom (1l. 1652-54). In these comparisons, the control of emotions is compared to traditional masculine virtues. This gender aspect is made explicit in the virgins' comment that Ifis's fearlessness defeats the heart of a man..$^{23}$ The comparison echoes and contradicts the Steward's earlier comparison of a man's poised heart to the agitated state of a woman's emotions: 'A fragile woman will too quickly lean / To thrill or grief: a man's heart holds the mean / Twixt both, and knows his destiny can waver. ${ }^{24}$

Ifis's patience and fortitude can perhaps be said to be unwomanly, but it could also be argued that the play shows that the Steward's voice of reason is not always right. Vondel's prefatory poem, for example, also prefers feminine patience to a male example. It presents Ifis, rather than Jeptha, as the heroine of the play, compares her with Isaac and states that 'this virgin exceeds all men [...] the strongest gives in to the weakest sex. ${ }^{25}$ Indeed, the poem views her as a forerunner of Christ in her willingness to be sacrificed (1. 32). This valuation of feminine patience and fortitude over traditional idealizations of masculine violent conquest is described as a historical phenomenon of the late seventeenth century by Mary Beth Rose, who argues that in that period in England 'the heroics of endurance, gendered normatively as female, had achieved sufficient prestige to become the primary model of literary heroism. ${ }^{26}$ Viewed from this English context, then, it could perhaps be argued that Vondel's contemporaries may not have agreed with the way modern Dutch critics portray Ifis. Rather than emotionless or a

22 'Heeft een stercker maght / Onder zich gebragt / Dan die heiren overwint' (ll. 1643-45).

${ }_{23}$ 'Die het mannenhart / In het knielen tart, / Met ongezwicht gelaet.' (ll. 1686-88).

24 'Een teêre vrou spat uit, al t'ongelaetigh, / In weelde en druck: een manshart draeght zich maetigh / In beide, en kent het weifelende lot' (ll. 85-87).

${ }_{25}$ '[M]enighmael tooneelen zaeght in traenen' 1. 35; and 'deze maegth gaet al de mans te boven [...] De sterckste zwicht voor d'allerzwackste kunne', 11.15 and 17.

${ }^{26}$ Rose, Gender and Heroism, p. 86. 
bore, she may have been seen as a truly heroic character. It is crucial to my argument that the play repeatedly stresses that Ifis achieved her patient acceptance of her fate through the expression and purgation of her violent emotions in an isolated environment reminiscent of a theatre.

\section{Rocks and Waves: Poetics and the Gender of Emotions}

The motherly love of Ifis's mother Filopaie - to which her name also refers - is contrasted to Jeptha's strict adherence to his vow throughout the play. In Vondel's description of the operations of catharsis in his prologue to the play, the emotional trajectory of Jeptha's wife Filopaie from happiness to sadness and vengefulness is paralleled to that of Jeptha's path from manly behaviour in the war to recklessness and stubbornness, melancholic shock and finally remorse, because both these trajectories in Vondel's view contribute to the effect of catharsis: they 'deliver their force with a powerful emotional effect. ${ }^{27}$ Nevertheless, critics have not considered Filopaie important to the poetics of the play. Instead, they seem to have followed the Steward in his opinion of her excessive emotions. He compares her love for her daughter to that of a tigress or a lioness, who will take bloody revenge when she finds her nest robbed of her young: she will thrust her nails into the attacker's eyes (1l. 1303-16). Sneller writes that Filopaie's natural urge to love her daughter is overpowering, and suggests a lack of reason, a characteristic shared by the mother animal and the human mother. She remarks that the Steward's representation of Filopaie as hysterical stays with the audience throughout the play, and has led critics to read her as such. ${ }^{28}$

I will argue that the Steward's view of Filopaie should not be read as representative of the tragedy as a whole. One of the reasons for this is that other characters use the image of parent animals in a much more positive light. Korsten has remarked that Jeptha, after his realization that it was wrong to execute his vow, also compares himself to a wild

27 '[...] om hunne kracht met een machtige beweeghenisse te baeren' ('Berecht', 11. 66-67).

${ }^{28}$ Sneller, 'De marges centraal', pp. 7 and 9. A notable exception is Frans-Willem Korsten, who explicitly comments on Konst's interpretation of Filopaie as a hysterical woman, and suggests an alternative, gendered reading of the play (Korsten, Vondel belicht, p. 74; Sovereignty as Inviolability, p. 73). 
animal when he cries out that even a wolf does not kill its own young. ${ }^{29}$ What is more, the Judge explicitly associates the image of the tiger who protects her young with maternal love and the sacrifice of Christ. He argues that the love between parents and children is a law of nature, shared by humans and animals. He not only refers to the natural behaviour of female lions, bears and tigers, but also to the Pelican, a Renaissance symbol for the self-sacrificing Christ, also used as such on the title page of Vondel's Altaergeheimenissen (Secrets of the Altar, 1645).

The pelican, when droughts are at their worst,

Does not allow its young to suffer thirst,

But pecks herself the arteries in her breast,

And draws her own heart's blood, so that the nest

May drink, her life-blood for their food outpouring.

You hear the lion, and bear, and tiger roaring

And raging if the hunters threat their lair. ${ }^{30}$

The Steward's view of Filopaie, then, need not be representative of the play as a whole. He represents the voice of reason (1. 434), and consequently - as the Berecht also stresses (11. 104-06) - does not operate from the heart, but from the head: 'So grave a matter needs much serious thought. ${ }^{31}$ His reasoned opinions, however, are always contrasted with more emotional alternatives in the play. Ifis calls him a deceiver who tries to separate him from her mother: 'We know your dissimulation, / Sending my mother at this time from this place. ${ }^{32}$ She too views Filopaie as a loving mother, and stresses that filial love is so strong as to materialize even after death: her corpse would utter her last word if her mother kneeled beside it. The Chorus that follows immediately upon the Steward's call for 'serious thought' similarly refers to family bonds when it asks whether the grey hair of Ifis's grandfather, patriarch Joseph,

\footnotetext{
${ }^{29}$ Korsten, Vondel belicht, p. 75; Sovereignty as Inviolability, p. 74. Interestingly, the tiger in that quotation is still seen as the Steward would also regard it - as a ravenous predator that Jeptha managed to subdue, as he did giants and heathens.

${ }_{30}$ 'De pellikaen, by mangel van den regen, / En water, laet de jongen niet verlegen, / Maer opent zelf alle aders in zijn borst, / En tapt het bloet van 't hart, om hunnen dorst / Te lesschen, hen te spijzen met zijn spieren. / Gy hoort den leeu, en beer, en tyger tieren, / En brullen, zoo de jager 't nest berooft' (ll. 1027-33). Note that Peter King applies a shift in the sex of the Pelican: it is a male bird in Vondel's original. The Pelican was used as an image of Christ in the early modern period.

31 'Zoo groot een zaak eischt rijp beraet, en zinnen' (1. 720).

32 ' $[\mathrm{M}]$ en kent uw loze streecken, / Die moeder, voor mijne aenkomst, stiert van kant' (ll. 488-89).
} 
would not stand on end if he heard of her fate. The Chorus suggests that her grandfather would have protected her from the sword, because he would not have been able to see his grandchild harmed (ll. 721-36). The Steward's adherence to reason, then, is contrasted in the play with other images that positively portray the emotions of motherly love and family bonds.

Another image used by the Steward to portray women as excessively emotional is also challenged by the play. The Steward uses the image of tides and waves hitting the shore when he contrasts a man's heart to that of a woman's in the opening scene of the play. Whereas a woman's heart is swayed by fortune and misfortune alike, a man's heart knows how to hold the mean: 'For good and evil know / Allotted times and turns, like ebb and flow. ${ }^{33} \mathrm{~A}$ man, then, is not carried with the waves of the tide, but resists that movement and holds the mean, in the Steward's view. He distrusts the tidal movement of the sea, and uses images of ships that sink when the breakers dash against the coast (1. 1301). At other moments, however, the image of tides and waves is used with a different import. When Jeptha ignores the Priest's advice to give free rein to his emotions and remains true to his bond, the priest compares him to a rock in the sea that does not heed the sound of the waves breaking on the shore. ${ }^{34}$ The Steward's image of the man's heart unswayed by the tide is echoed here, but in a much more negative sense: Jeptha's reason, according to the Priest, is clouded, and the rock here designates cold-heartedness rather than steadfastness.

Since both the Steward's image of the tigress as well as that of a rock standing firm despite the pull of the tide are contrasted with other interpretations of those images in the course of the play, I think neither the Steward's opinion of Filopaie nor his opinion of gender and emotions should be taken as representative of the play as a whole. Indeed, I would suggest that with the figure of the Steward, the play introduces a remnant from earlier Senecan drama as a contrast to a radically different model of dealing with emotions. Gender contrasts are used to set off the differences between these two views. The figure of the Steward resembles that of the nurses in Seneca's tragedies, who try to reason with furious heroines such as Medea or Clytemnestra in stichomythic

\footnotetext{
${ }_{33}$ '[Q]uaet en goet / Elck heeft zijn tijt, en beurte, als eb, en vloet' (ll. 91-92).

34 'Kon een gety oit stercker gaen, / Wanneer de zee op strant en steenrots barrent, / Ter helle daelt, en oprijst aan 't gestarrent!' (1l. 618-20); and 'Ja, gelijck een rots in zee / Naer 't barnen en gebruisch der baren luistert' (1l. 1185-86).
} 
exchanges such as those of Jeptha with the Steward in 11. 915-25. The Steward's influential image of Filopaie as a vindictive tigress similarly finds its roots in Seneca, where it is often used to portray the uncontrollable nature of feminine vindictive fury (see, for example, Seneca's Medea, 11. 862-65, where, ironically in the context of the subject of Vondel's tragedy, it is used to portray Medea's infanticidal vindictiveness).

Vondel's Jeptha contains more Senecan elements. It resembles the tragedy Hercules furens, in which a hero who has just returned from battle also kills his offspring. There, the goddess Juno takes revenge on the mythical hero Hercules. She lets the Furies possess him and drive him to madness. Believing that he sees his archenemy, the tyrant Lycus, Hercules mistakenly slays his wife and son. Only when he recovers from his fury does he realize what he has done. Vondel's Jeptha echoes this play in many ways. Like Hercules, Jeptha returns victorious from the wars, and like him, he slays what is dearest to him at the altar. He too cynically compares his heroic feats on the battlefield to the shedding of the blood of his own kin (1. 844, or 1l. 651-53). Also like Hercules, Jeptha speaks of his hand that used to fight battles, but that now kills his child (ll. 1714-15), and shows remorse only after the deed is done. Similarly, in her vindictiveness, at the altar Filopaie mistakenly thinks she sees her husband before her, as Hercules saw Lycus, and wants to kill her own partner in her fury.

Vondel's Jeptha, however, does not simply imitate Seneca's tragedy. In accordance with Stoic philosophy, Hercules furens stresses the dangers of the passions, and uses feminine fury as an example of the effects of uncontrolled emotion. Vondel's play, however, reverses this view of the passions. It is not Jeptha's passionate fury that drives him to the murder of his daughter - instead, the play emphasizes how he swallows his feelings to carry out his vow. If Stoic philosophy fears the effects of passion, Vondel's Jeptha shows that the expression of anger and grief in an isolated, theatrical environment can moderate those passions. This contrast also appears in gendered terms: Seneca prefers masculine reason over feminine passion, but in Vondel's play it is the ideal of masculine repression of emotions recommended by the steward that is represented negatively, the female characters' expression of emotion is shown to lead to temperance.

Indeed, the play as a whole represents masculine repression of emotions in a negative light. Although Jeptha tears his clothes in grief and shock when Ifis is the first creature to appear out of his house upon his 
return from battle (11. 819-23, see also the title page of De Koning's tragedy - figure 1), he has since adhered to the Steward's advice of moderation. He has 'painfully suppressed the grief' and feels as if his heart is caught in a vice. ${ }^{35}$ The Steward approves of this strategy, for when Jeptha longs to express his feelings - a process he genders feminine by comparing it to the painful pangs of giving birth - the Steward reminds him of his manly duty to remain rational: 'You used to bear yourself more manfully / On parting. ${ }^{36}$

Whereas Ifis used her two months of withdrawal to purge her emotions, Jeptha went away to battle to repress his grief. He complains that he could not express his sorrows openly: 'Others show their grief and vent their feelings, / But I suppressed my sighs in all my dealings, / And night and day my sorrow put behind. ${ }^{37}$ Peter King here translates the Dutch 'inkroppen' with 'put behind', but the term is more literally translated as 'swallowed', or 'compressed inside.' It is very much a physical term: rather than purging his grief, he has contained it inside his body. Because Ifis has used the two months of withdrawal to come to terms with her emotions, she is able to face her fate with patience. Jeptha, however, has swallowed his emotions during these two months, and is still in the same emotional state as the moment he saw Ifis come out of his house on his return from battle. Consequently, he once more starts to tear his clothes at the altar, for Ifis entreats him: 'Ah father, do not rend your garments so. ${ }^{38}$ The Court Priest suggests that the two of them withdraw a little, possibly so that Jeptha can purge his emotions in a controlled environment. Moreover, he is worried that Jeptha 'will alarm [Ifis's] heart with all this grieving.. ${ }^{39}$ Similarly, Filopaie suggests that the violence of her emotions at the death of her daughter might have been tempered if she had been offered an opportunity to come to terms with the impending sacrifice. ${ }^{40}$ Using the same word 'inkroppen', she complains that her heart will have to swallow her woe forever since

\footnotetext{
35 '[...] mijn hartewee met knaegen / In 't hart gesmoort' (1l. 856-57); and 'Hoe wordt mijn hart beklemt, gelijck met schroeven!' (1. 840).

36 'Gy hebt voorheene u moediger gedraegen / In 't scheiden' (1l. 855-56).

37 'Een ander melt zijn' rouw, magh zich verluchten, / Maer ick ontzagh en vreesde een' zucht te zuchten, / En kropte mijn verdriet in nacht en dagh' (1l. 803-05).

38 'Ay vader, scheur uw kleeders niet aen flarden' (1. 1184).

39 'De lantvooght ga met my wat aen een zijde' (1. 1527); and 'Gy zult haer hart door dit gekerm vertsaegen' (1. 1543).

40 'Och, liet men my ten minste haer eens spreecken, / Voor 't allerjongst: zoo hadde ick noch mijn hart / Eens uitgeklaeght: nu kropt het deze smert, / Dit wee, en zal 't inkroppen al zijn dagen' (ll. 1876-79).
} 
she was not allowed to prepare for her daughter's death by grieving together with her. A closer examination of the emotions of the female characters, then, reveals that they are not so much secondary to the actions of Jeptha, but offer alternatives to his management of emotions. Whereas Jeptha is advised to repress his excessive grief to come to rational decisions, the female characters are shown to express their violent passions in a secure environment and are afterwards more able to cope with tragedy.

\section{Breaking Waves: Catharsis and Galenic Medicine}

The view of the emotions as presented by the play is expressed most clearly by the Court Priest, who conflates Aristotelian poetics with Galenic medicine in his interpretation of the operations of the passions. Galenic medicine associates the emotions with the four humours (blood, phlegm, black and yellow bile). Through ingestion and purging, the individual is able to achieve a healthy balance in the humours. The Court Priest similarly takes a physical approach to the emotions, and stresses the importance of purging. ${ }^{41}$ The idea of catharsis is primarily a medical metaphor. Katherine Craik writes that, given Aristotle's knowledge of the purging of peccant matter by the application of drugs in medical discourse, 'Aristotelian katharsis can be seen as the precursor of the early modern development of humoral theory. ${ }^{42}$ The scene in which the Court Priest presents his ideas on the operations of the emotions focuses on Filopaie's grief and anger after the sacrifice of her daughter. The Court Priest stands by Filopaie's side when her vindictiveness towards her husband does indeed materialize in the way the Steward had predicted. Unlike Hercules or Jeptha, however, Filopaie does not murder a family member. Instead, her performance of fury eventually contributes to the moderation of her emotions. The Court Priest leads her through a process of purgation during which he makes sure that she can hurt neither others nor herself (ll. 1779-87). He comments that reason cannot stop the flow of grief: it needs to run its course (11. 1779-80). Therefore he lets Filopaie play out the murder of her husband on the altar scene, a space that earlier in the play is compared with a theatre. She imagines that she sees Jeptha before her and

41 See also Konst, Woedende wraakghierigheidt, p. 28.

42 Craik, Reading Sensations, p. 46. 
describes how she attacks him, like a tigress bereft of her young. She even imagines that she changes into a werewolf, the creature on the boundary between human and animal, and digs her claws into her husband's body. ${ }^{43}$ This performance of grief and anger, stage-managed by the Court Priest, leads to catharsis. As in Ifis's case, Filopaie's expression of grief is echoed by mountains, vaults and caves (1l. 1814-16), and she is supported by the virgins. In both Ifis's and Filopaie's case, the feminine expression of emotions in a sheltered environment that is compared to a theatre is shown to be more effective than Jeptha's attempts to suppress his feelings, and is shown eventually to lead to a balanced state of mind. ${ }^{44}$ Even the Steward, who initially asks 'what means we have to rock the grief to sleep?', later agrees with the Court Priest that 'a breaking heart in mourning gains relief'. ${ }^{45}$ In the final act of the play, both Jeptha and the Steward seem to realize that the expression of emotions is a natural process that enables rather than prevents rational decisions.

The fact that the play as a whole adheres to this Aristotelian-cumGalenic view of the passions is also evident from Vondel's use of the image of breaking waves in his 'Berecht.' There, the image is not used in the Steward's sense of rocks standing firm in a tide of passion. Rather, it describes the flow of passions in the play: 'Thus the various passions toss, tumble and break like waves on the shore, by constant changes from beginning to end. ${ }^{46} \mathrm{An}$ audience riding the waves of staged passion will learn how to moderate their emotions (1l. 141-43). The effect of words on the body plays a crucial role in this process. Vondel claims that his use of iambic pentameters is especially suited to his purpose, since they are more sinewy and muscled than Alexandrines (1l. 14659). ${ }^{47}$ Tanya Pollard writes that: '[1]iterary language, especially when

43 'Daer ruck ick hem zijne oogen uit het hooft, / Dat valsche hart ten boezem uit, de darmen / Ten buick uit. ziet hem spartlen: hoort hem kermen.' (1l. 1854-56)

${ }^{44}$ Interestingly, women were considered by Galenic medicine to have an advantage over men. Michael Schoenfeldt writes that this was because 'their monthly menstrual flow functioned as a purge, accomplishing naturally what men would have to achieve through blood-letting. (Schoenfeldt, Bodies and Selves, p. 37).

45 'Wat middel om den rouw in slaap te wiegen?' and 'Een treurigh hart is met geklagh behulpen' (ll. 1888 and 1928).

46 'Aldus woelen, tuimelen, en barnen hier verscheide hartstoghten, door geduurige veranderingen van den beginne tot het ende' (1l. 123-25; my translation, KS).

${ }^{47}$ For a wonderful exploration of early modern ideas about the effect of literary language on the body, see Craik, Reading Sensations. On the relation between emotions and the stylistic form of language in Jeptha, see Van Leuvensteijn en Wattel, 'Een statistische methode? 
spoken aloud, was understood to be directly linked with the imagination and to have special rhetorical properties, taking on a synaesthetic power to transform the body at a physiological level. ${ }^{48}$ Moreover, the published text of Jeptha suggests that a visit to the theatre is an ideal place to vent one's passions in a controlled environment and once more associates this idea with a woman - just as Ifis and Filopaie vented theirs in isolation, so the dedicatee of the play, Anna van Hooren, is known for shedding tears in the theatre (Dedicatory poem, 1. 35).

\section{Words Made Flesh: Vondel's Poetics and Catholic Purgation}

Vondel's use of Aristotelian poetics is exceptional in a Dutch context, as well as in a broader perspective. Konst writes that 'nowhere in the Europe of the 1660s does one find plays that breathe the spirit of Aristotle, that execute his ideas to such an extent as Vondel's tragedies. ${ }^{49}$ How can this phenomenon be contextualized? With respect to this issue, Korsten remarks that poetics do not exist in a vacuum. A play's poetics is not merely a (diachronic) reaction to earlier poetics, but functions synchronically in a particular social, religious, or political context. ${ }^{50}$ Jeptha's gendered representation of the emotions is strongly related to the biblical subject matter of the play as well as to religious conflicts in the Netherlands of the seventeenth century. ${ }^{51}$ Jeptha's strict adherence to his vow is represented as Calvinist, whereas his later realization of the importance of his emotions is associated with Catholic images in the play.

Jeptha's central theme has been defined as 'the relation between God and Man', and Korsten has situated the play in the context of the debate on predestination that raged in post-Reformation Europe. ${ }^{52}$ In criticism of the first half of the twentieth century, this context was more regularly integrated into analyses of the play. There, Jeptha was

48 Pollard, Drugs and Theater, p. 16.

49 Konst, Woedende wraakghierigheidt, p. 289.

${ }^{50}$ Korsten, Vondel belicht, p. 76; Sovereignty as Inviolability, p. 74.

51 In a different context, Parente also describes Vondel's Jeptha as 'Christianized poetics' and writes that the programmatic neo-classical intention of Vondel's tragedy is 'to induce his Christian audience to lament their fallen state, recognize the paradoxical relationship between faith and reason and to evince their belief through their unreserved submission to God's will' (Religious Drama and the Humanist Tradition, p. 147).

52 Konst, 'De motivatie van het offer', p. 156 and Korsten, Vondel belicht, p. 72; Sovereignty as Inviolability, pp. 77-79. 
compared to a Calvinist who does not listen to the priest who offers him a possibility of absolution, but listens only to his own conscience, and adheres to his own strict interpretation of his vow. ${ }^{53}$ In contrast to Buchanan's Jephthes (1554), Vondel's play explicitly condemns this attitude: Jeptha realizes he was wrong to murder his daughter and turns to the church to beg for the forgiveness of God. Jeptha's development from a man who lets his adherence to his vow prevail over his emotions to an Aristotelian protagonist who purges his body of excessive emotion seems to run parallel to his development from a Calvinist believer in his personal relation to God to a Catholic who has faith in the intermediary role of the church as well as in a process of spiritual purgation that leads to forgiveness. ${ }^{54}$ There are several reasons why I would characterize this process of spiritual purgation as Catholic. Firstly, it is of a strongly physical nature: the experience of pain is central to Jeptha's remorse. Of course, the idea that the experience of physical pain could lead to salvation is embedded in the Catholic faith. ${ }^{55}$ To be forgiven, Jeptha would be prepared to climb steep rocks and would cross thorncovered valleys barefoot - no pain would be too severe. In an even more explicitly Catholic vein, Jeptha also suggests wearing a hair shirt, recalling the customs of monastic penance:

If some way I could find

To expiate my sin, there is no pain

I would not undergo; [...]

No glen would seem too drear or deep, no crest

Too steep to clamber up and down them yet

Through thorns and brambles, barefoot, bathed in sweat

And gasping for my breath. Sackcloth I'd wear

And ashes to express my heart's despair

${ }^{53}$ In the 1930s, interpretations of Vondel more frequently stressed the relation of his work to religious conflicts, and emphasized the role it played in shaping paradigms in the debate. Gerard Brom in Vondels geloof, for example, writes that Vondel's plays are heavily related to the religious conflicts of his time. 'A generation that grew up in the turbulent days of the Bestand learns to debate religion systematically and can only be fascinated by a play when it is full of exchanges of ideas that really touch the hearts of audience as well as players' (p. 286; translation my own). Verwey wrote that '[w]e understand Jeptha entirely if we are aware of a conflict between human feeling on the one hand and religious feeling on the other' (Verwey, 'Vondels Jeptha'). Simons has analyzed the play in the context of religious controversy (Simons, Studies en Lezingen).

${ }_{54}$ Interestingly, Samuel Coster in his Iphigenia (written in 1617, first performed in 1621) also used a story of the sacrifice of a child to criticize Counter-Remonstrant preachers.

${ }_{55}$ On the impact of the Reformation on cultural assumptions about pain, see Van Dijkhuizen, 'In Thy Passions Slain' and 'Partakers of Pain'. 
In solitude, in forest or wild plains.

Consider well, assemble all the pains.

All miseries and torments, all the grief:

If only God will grant me some relief

I will not turn away from rigours stern. ${ }^{56}$

The proposed process of purgation would take place in a remote area characterized by steep rocks and valleys, an isolated environment reminiscent of Ifis's refuge in the mountains of Galaäd. When Jeptha experiences remorse in the final act of the play, then, he expresses his pent-up emotions and intends to retire to an isolated area, as his daughter also reports she did in the beginning of the play. The word 'grief' in the quotation translates the Dutch 'geklagh', which refers expressly to the utterance of grief. Thus the tragedy has come full circle with Jeptha's realization that it is necessary to express one's emotions in an isolated environment in order to come to terms with them.

It is not only Jeptha's painful process of purgation that is intensely Catholic. Indeed, Vondel's adherence to Aristotelian poetics in a landscape of Senecan drama can be related to a Catholic view of the relation between word and flesh. That the use of visual representations was associated with Catholicism by iconoclast Puritans and Calvinists is of course well known (and the effect Vondel accords to Vos's visual pantomime after Act Four is interesting in this context; 'Berecht', 11. 131-44). However, in an English context at least, strict Protestants also objected to the idea that words could bring about an alteration in a listener's body. In her Drugs and Theatre, Tanya Pollard provides a sharp analysis of English debates about the physical effects of theatre. She writes that such quasi-magical powers of language were heavily contested, especially in discourses of science and Protestantism. William Perkins, for example, objected that 'that which is onely a bare sound, in all reason can have no vertue in it to cause a reall worke'. In his view, words cannot have 'the power of touching a substance'. In these debates, the idea that words could have a physical effect was associated with Catholicism. ${ }^{57}$

56 'Verstont ick langs wat wegh / Dit lasterstuck te zoenen stont, geen lijden / Viel my te zwaer.[...] / Geen steile rots viel my te steil, geen dal / Te droef, te diep, in op en neêr te stijgen, / Door doornehaegh, baervoets, bezweet, te hijgen / Naer mijnen aêm. Ik trock een hairenkleet / Aen 't lijf, en vaste in asch en harteleedt, / In eenzaemheit, en wouden, en woestijnen. / Bedenck vry, hael te zamen alle pijnen / Weedommen, en verdrieten, en geklagh: / Indien ick Godt alleen vermurwen magh, / Geen strengheit zal my hinderen, noch keeren' (1l. 1738-51).

57 Pollard, Durgs and Theater, p. 135. 
Puritan treatises that attacked the theatre did acknowledge the power of the speech act in the theatre, but were highly suspicious of its effects on the audience: they saw it as a danger rather than a positive effect of theatre.

That the gendered representation of emotions in Jeptha is closely intertwined with the poetics of the play as well as with its religious context, is also supported by Vondel's work in a different genre. In Vondel's poetic contribution to the debate about predestination, the contrast between reason and a strict adherence to Protestant doctrine on the one hand, and 'natural' feminine emotions on the other, also figures prominently. In 1631, Vondel published a poem entitled Decretum horribile (The Horrifying Judgement), a sharp attack on Calvin. ${ }^{58}$ The poem uses the forceful image of a mother who has lost her child to bring home the cruelty of the Counter-Remonstrant doctrine of double predestination, according to which the mother could have done nothing to prevent her baby from going to Hell. It asks whether God demands the cruel sacrifice of children:

Is God the crocodile that eats the new-born child

For dainties, on the banks of river Nile?

Where Moses in his chest was scarcely held

Floating amongst the women's cries of murder

Through bodies without count? ${ }^{59}$

This image also features in Jeptha, at a meta-dramatic moment where the chorus of virgins has just intervened in the action of the play to request that Ifis's mother be present at her sacrifice. The Steward has refused this request because he fears Filopaie will behave like a tigress bereft of her child. In the chorus that follows, the virgins compare Ifis to Moses, and Filopaie to Jochebed, his mother. They sing of the mother's fears and grief as she hands her child over to the waters of the Nile. Even though the crocodile is not compared to God in the play as it is in the poem, the ravenous animal does spare the child. By recycling the images as well as the theme of the 1631 poem, the chorus seems to comment on Jeptha and the Steward's lack of compassion, and compares them to Calvinists. The poem Decretum horribile ends with words

\footnotetext{
${ }^{58}$ See also Konst, Fortuna, Fatum en Providentia Dei, pp. 69-71.

59 'Is God de krokodil, die 't versch geboren kind, / Aen d'oevers van den Nijl, voor leckerny verslind? / Daer Moses nauwelicks in 't kistje, word behouwen, / En drijft, door 't moordgeschrey der Isralijtse vrouwen / Door lijcken zonder tal?' (ll. 69-73). I thank Helmer Helmers for helping me with this translation.
} 


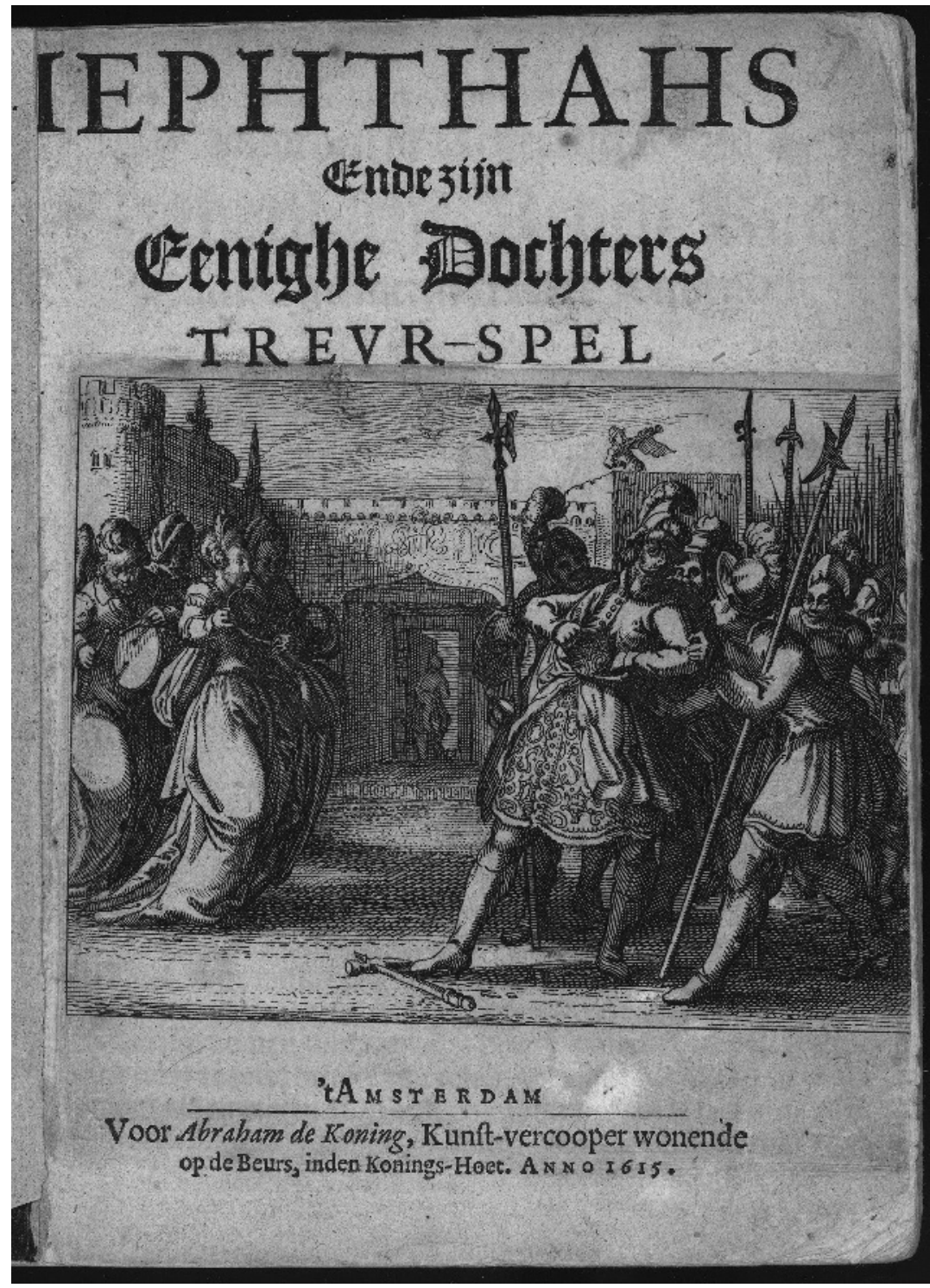

Title page of the 1615 edition of De Koning's Jephthah. To the left stand Ifis and her virgin chorus, while the army to the right supports Jeptha, who has dropped his sword and tears his coat in an emotional reaction to his daughter's appearance. With the courtesy of the University Library Amsterdam. 
of comfort to the mother - even if the infanticides ('kindervlegels') of the Calvinist faith proclaim such cruelty, Christ has shed his blood for her child: 'He gathers them in lap of new Jerusalem / More loving than a mother hen in the fields / That with her wings the naked chick protects and shields. ${ }^{60}$ Here too, then, maternal love and the extreme emotions that are associated with it are contrasted to the strict adherence to Protestant dogma, which is represented as unfeeling.

\section{Conclusion}

I have argued that Vondel's Jeptha contrasts masculine repression with the feminine expression of passion, and shows the latter to be a more 'natural' and even more ethical approach to life. Previous interpretations of the play in terms of character and plot have viewed its female characters as sanctimonious or hysterical, but they are in fact central to the play's representation of the workings of emotion. The play uses a gendered representation of the emotions to counter a prevailing Senecan poetics in the Low Countries, which it associates with a strict Protestant outlook on the relation between human beings and God. In its stead, it employs female characters to propose a mix of Catholic, Aristotelian and Galenic paradigms - a framework that allows for a process of physical and spiritual purgation in a safe environment. This process of purgation leads to equanimity and, eventually, absolution. Vondel's tragedy in its gendered representation of the purgative effects of the performance of emotions is a spirited neo-Aristotelian defence of the affective operations of the early modern stage.

${ }^{60}$ 'Hij saemeltse, in den schoot van 't nieu Ierusalem, / Veel lieflicker als een klockhen, met haer' wiecken / Beschaduwt en beschermt het ongepluymde kieken' (1l. 13032; my translation, KS). 